\title{
ОСОБЕННОСТИ СОВМЕСТНОГО ЗАВЕЩАНИЯ СУПРУГОВ И ЗАВЕЩАТЕЛЬНОГО ОТКАЗА
}

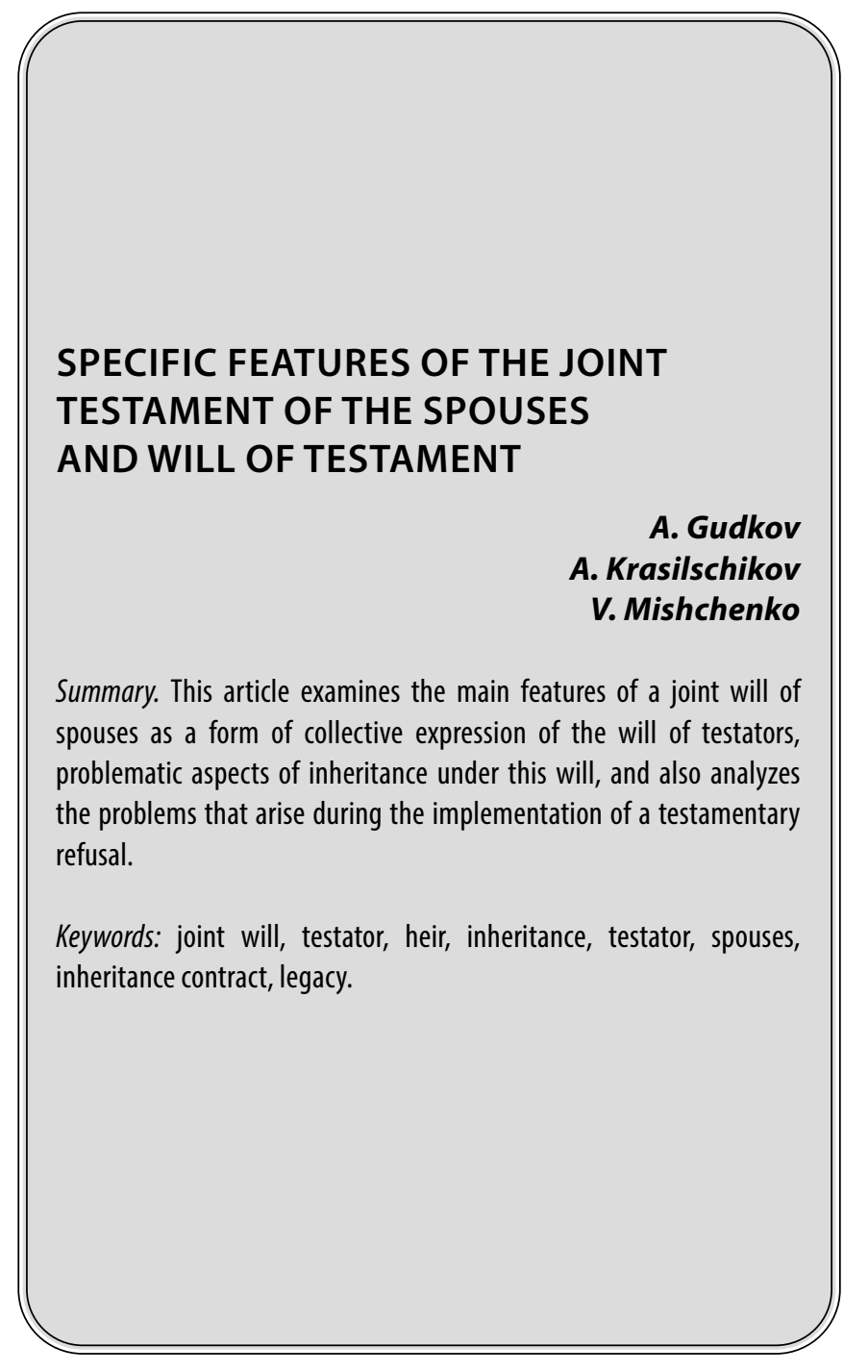

3 авещание - форма распорядительного акта в отношении имущества лица после его смерти. Завещание составляется наследодателем при жизни с целью установления круга наследников, но при этом сохраняется право завещателя на управление имуществом при жизни.

С введением 18.07.2018 года законодательных изменений в статью 1118 ГК РФ завещание приобрело коллективную форму, так как супруги получили право на оформление совместного завещания. Его важным условиями являются: нахождение супругов в браке, наличие совместно нажитого имущества, а также дееспособность каждого из супругов [1]. Специфика совместного завещания
Гудков Анатолий Иванович

К.ю.н., дочент, ВЮИ ФСИН России

gudkovaniv@yandex.ru

Красильщиков Анатолий Владимирович

К.ю.н., дочент, ВЮИ ФСИН России

krasilschikov@inbox.ru

Мищенко Вячеслав Иванович

К.ф.н., дочент, ВЮИ ФСИН России

vyacheslav-mischenko@mail.ru

Аннотация. В данной статье рассмотрены основные особенности совместного завещания супругов как формы коллективного выражения воли завещателей, проблемные аспекты наследования по данному завещанию, а также проанализированы проблемы, возникающие при реализации завещательного отказа.

Ключевые слова: совместное завещание, наследодатель, наследник, наследство, завещатель, супруги, наследственный договор, завещательный отказ.

позволяет определить доли наследников по обоюдному согласию сторон и распорядиться наследством по своему усмотрению, в том числе завещатель вправе лишить наследника наследства или предусмотреть завещательное распоряжение, которое в будущем обяжет наследников совершить определенные действия. Несмотря на нововведение в законе, большинство семейных споров по наследству возникают в суде из-за оспаривания наследниками совместного завещания супругов.

Актуальность данной темы заключается в необходимости анализа проблемы совместного завещания супругов, возникновении споров по неравномерности долей наследников. 
Исходя из положений статьи 1124 ГК РФ, основной причиной недействительности завещаний является несоблюдение определенных правил. В частности, к распространенным нарушениям правил относят: отсутствие даты и места составления завещания, неточные данные о наследниках, в том числе ошибки в написании их фамилий, дат рождения или места регистрации лиц. При установлении нарушений в составлении совместного завещания несогласные наследники тем самым получают право на обжалование завещания и признания его недействительным в судебном порядке.

В целом введение новеллы о совместном завещании супругов направлено на снижение в обществе конфликтных ситуаций в вопросах принятия наследства и на реализацию воли наследодателей - супругов, которые вправе при жизни определить возможный вариант раздела имущества после их смерти [2].

На наш взгляд, важная функция совместного завещания супругов - это соблюдение личных интересов до момента их смерти. Например, пережившему супругу не придется спорить с наследниками умершего супруга, так как момент их принятия наследства после одного из них отсрочен до смерти второго супруга. В свою очередь, наследники вступят в наследство на имущество завещателя только после смерти обоих супругов. Таким образом, данная норма является гуманной для супружеской пары и снижает степень конфликтности между родственниками, так как не допускает немедленное деление долей супружеского имущества вследствие смерти одного из супругов - наследодателя.

В отличие от наследственного договора, нацеленного на урегулирование отношений между наследодателем и наследниками на прозрачных условиях при его жизни, совместное завещание супругов - это односторонняя сделка, которая не порождает прав и обязанностей у наследников, если они не примут условия завещания и не вступят в наследство [3]. В частности, это важно при наследовании неисполненных обязательств наследодателя, которые перейдут к наследнику лишь в том случае, если он проявит свою волю. При этом наследственный договор - двусторонняя сделка, которая вступает в силу при жизни наследодателя, и после его смерти возлагает на наследников обязательства независимо от их воли, в том числе по неисполненным обязательствам умершего, например, при выплате его кредиторских долгов. Однако, заключить наследственный договор одновременно со всеми потенциальными наследниками не представляется возможным [4]. Кроме того, заключение наследственного договора при жизни лишает завещателя его имущества и, в случае нарушения наследственного договора со стороны родственников, увеличивает степень беззащитности завещателя.
Таким образом, принятие законодательных изменений относительно заключения совместного завещания супругов решает, на наш взгляд, несколько задач: реализует волю наследодателей в отношении раздела их имущества после смерти, справедливо учитывая интересы каждого наследника; распределяет объем неисполненных обязательств супругов между наследниками; предоставляет наследникам возможность выбора при принятии наследства либо отказе от него; учитывает права пережившего супруга до момента его смерти, а также максимально защищает интересы завещателей.

Вместе с тем, существуют и пробелы законодательного урегулирования по вопросу совместного завещания супругов. В реальности переживший супруг может не являться титульным владельцем имущества умершего супруга, например, не быть единым владельцем доли в компании, поэтому возможность управления его долей будет ограничена, так как никто из наследников не сможет вступить в наследство после его смерти ввиду невозможности принятия наследства в полной мере вследствие наличия законных прав у пережившего супруга, который, в свою очередь, также не может вступить в права наследования долей в капитале юридического лица после смерти супруга в силу установленных законом условий совместного завещания супругов.

Таким образом, управление и распоряжение долей в уставном капитале хозяйственного общества титульного владельца ограничено обстоятельствами, которые невозможно разрешить до смерти второго супруга. Кроме того, нотариусы не вправе выдавать распорядительный акт на временное управление капиталами титульного владельца (счета в банках, акции, доля в уставном капитале общества), что, с одной стороны, создает угрозу потери или снижения стоимости активов умершего супруга, а с другой - парализует деятельность компании, если доля умершего супруга в ней составляла $31 \%$ и более. Например, решение о внесении изменений в устав принимается $3 / 4$ участников хозяйственного общества. Если доля умершего супруга составляла 31\%, такое решение не может быть принято обществом в силу объективных причин. Соответственно узаконивание изменений устава общества возможно только по решению арбитражного суда.

Вторая немаловажная проблема, возникающая при реализации совместного завещания супругов,- учет обязательной доли в наследстве, установленной законом. Дело в том, что круг лиц, имеющих право на обязательную долю в наследстве, может меняться: например, факт рождения ребенка или приобретенная инвалидность наследника, которая позволяет менять законный круг наследников независимо от воли завещателя. В этом случае возникают споры по совместному заве- 
щанию супругов: время вступления в наследство по совместному завещанию ограничивает права законного наследника, желающего вступить в наследство в общем порядке, независимо от наличия совместного завещания супругов. При этом законный наследник с обязательной долей в наследстве имеет приоритет перед иными наследниками и может дестабилизировать запланированные последствия совместного завещания. В этом случае требуется внести законодательные изменения, позволяющие урегулировать такие ситуации с обязательными наследниками без ущерба для пережившего супруга наследодателя.

Также стоит отметить, что составление совместного завещания по правилам нотариата является семейной тайной до момента смерти супруга, и нотариус, открывший наследство после смерти одного из супругов, физически не сможет выделить, какая именно часть завещания подлежит оглашению наследникам, и сохранить при этом тайну завещания второго живущего супруга. Например, законные наследники вправе в силу статьи 1131 ГК РФ оспорить совместное завещание супругов в суде и в процессуальном порядке ознакомиться с полным текстом совместного завещания супругов. Таким образом, тайна совместного завещания супругов будет прямо нарушена при жизни одного из супругов. В этом случае также необходимо внести законодательные изменения, обеспечивающие сохранение тайны совместного завещания супругов в случае его оспаривания наследниками и иными лицами.

Также неурегулированным остается вопрос, возникающий при реализации прав пережившего супруга по составлению нового завещания, которое автоматически отменит предыдущее завещание, а значит, и автоматически аннулирует совместное завещание супругов в силу изменения воли одного из них. Данный момент ярко свидетельствует о том, что воля умершего супруга - наследодателя является не до конца реализованной и часто зависит от воли второго, пережившего его супруга. В этом случае нотариусу приходится вместо реализации прав умершего завещателя по совместному завещанию прибегнуть к оформлению наследства по закону.

Таким образом, с учетом действующего законодательства, совместное завещание супругов как коллективная форма реализации воли завещателей имеет свои погрешности и проблемы с реализацией прав наследодателя, права которого не могут быть гарантированно реализованы после его смерти вследствие того, что должны быть соблюдены права иных лиц - оспаривающих завещание наследников, или изменения воли пережившего супруга. Устранение данных пробелов возможно при принятии норм права, подробно опи- сывающих ситуации при реализации совместного завещания, возникающие при определенных жизненных условиях.

Одновременно с тем, важно проанализировать завещательный отказ как новый вид завещательного распоряжения в наследственном праве. В юридической практике данный вид распорядительного акта называется легат, который означает будущее действие вступившего в права наследника по исполнению воли умершего, например, выплатить долг или передать имущество в пользу конкретных лиц в будущем [5]. В свою очередь, у легатария - отказополучателя по завещанию (третье лицо) возникает законное право требования от легата исполнения его обязательств. Фактически после смерти наследодателя между наследником и легатарием возникают обязательственные гражданские правоотношения, которые регулируются нормами ст. 1137 ГК РФ [1]. Завещательный отказ может быть реализован только при определенных условиях: после смерти наследодателя, при принятии наследства легатом, при жизни легатария, при наличии достаточной наследственной массы.

Исходя из этих условий, возникает ситуация, при которой исполнение обязательств перед легатарием является оспоримым иными лицами. Допустим, легат вынужден по решению суда выплатить долги наследодателя или исполнить иные его обязательства, при этом наследственной массы может оказаться недостаточно. Однако, законом не предусмотрено преимущественное право легата по принятию завещательного отказа как исполнение первоочередной воли наследодателя перед требованиями его кредиторов. В этом случае возникает дисбаланс интересов и несоблюдение приоритетности воли наследодателя. Учитывая непередаваемость прав легата по принятию завещательного отказа, иные наследники не вправе претендовать на передачу прав по переуступке или передачу этих прав иным способом. Таким образом, на наш взгляд, легат вправе требовать восстановления прав в порядке истребования из чужого незаконного владения имущества наследодателя, которое выбыло от легата вследствие вступившего в законную силу судебного акта или действий иных лиц до момента вступления легата в наследство. К примеру, обязанность легата предоставить в найм жилье родственнику умершего вместе с принятием наследства не может быть реализована, если это имущество перейдет к кредиторам по решению суда или наследникам по обязательной доле в наследстве, так как обязательство легата не передаваемо [6]. В целом полагаем, что права легатов и легатариев требуют более детального законодательного урегулирования с учетом баланса интересов и приоритетности их прав перед правами иных лиц. 


\section{ЛИТЕРАТУРА}

1. Федеральный закон от 19 июля 2018 г. № 217-Ф3 «0 внесении изменений в статью 256 части первой и часть третью Гражданского кодекса Российской Федерации»//URL: http://www.consultant.ru/document/cons_doc_LAW_302862/.

2. Демичев А.А. Совместное завещание супругов в Российском праве. Наследование по закону и по завещанию. - № 4.— 2018.— С. 9-11.

3. Беляев Р.В. Правовые основы распоряжения имуществом на случай смерти. «Экономика. Право. 0бщество».— № 1 (21). — 2020.— С. 18-33.

4. Черепанова 0.С. Наследственный договор как новелла российского гражданского права (критический анализ некоторых положений) // Нотариус.№ 2. - 2019.- - C. 41-44.

5. Демина И.А., Е.С. Омельченко. Завещательный отказ в наследственном праве: теория, практика и проблемы применения. Электронный научный журнал «Наука. Общество. Государство» 2019. Т. 7, № 1 (25) http://esj.pnzgu.ru

6. Постановление Пленума Верховного Суда РФ от 29 мая 2012 г. № 9 «0 судебной практике по делам о наследовании» C изM. на 24.12 .2020 г. // URL: http://www.consultant.ru/document/cons_doc_LAW_130453/.

(с) Гудков Анатолий Иванович ( gudkovaniv@yandex.ru ),

Красильщиков Анатолий Владимирович ( krasilschikov@inbox.ru ), Мищенко Вячеслав Иванович ( vyacheslav-mischenko@mail.ru ).

Журнал «Современная наука: актуальные проблемы теории и практики» 